\title{
INTERRELATIONSHIP BETWEEN WORK AND PRIVATE LIFE OF EMPLOYEES - CONFLICT OR BALANCE?
}

UDC 331.191.32

\author{
Milica Mladenović1 ${ }^{1}$ Bojan Krstić \\ ${ }^{1}$ Metropolitan University Belgrade, Faculty of Management, Serbia \\ ${ }^{2}$ University of Niš, Faculty of Economics, Serbia \\ ORCID iD: Milica Mladenović $\quad$ () https://orcid.org/0000-0003-3210-0316 \\ Bojan Krstić (ib https://orcid.org/0000-0003-4597-6819
}

\begin{abstract}
Contemporary companies consider work-life balance a crucial topic. Higher work pressure, longer working hours and more families with both working parents have made balancing work and private life even more difficult. The paper addresses this interrelation and highlights two research questions regarding the type of relationship (positive or negative) that exists between work and private life of employees. These questions are answered based on the analysis of various previously conducted empirical research studies. Findings reveal both negative and positive interrelationship between employees' work and private life. The contributions and conclusions of this paper can be extremely relevant for a company to comprehend how important the creation of work-life balance initiatives is for increasing job satisfaction of its managers and other employees, as well as for developing the reputation of a desirable employer.
\end{abstract}

Key words: work-life conflict, work-life balance, job satisfaction

JEL Classification: O15

\section{INTRODUCTION}

Due to changes in recent socio-demographic trends, such as a larger number of women entering the work field, more challenging work demands, faster lifestyles and increased need for elderly care (Mladenović \& Krstić, 2021b), it can be concluded that work and private life should not be viewed as two segregated parts of an employee's life, but rather as

Received May 05, 2021 / Revised July 08, 2021 / Revised July 21, 2021 / Accepted August 08, 2021 Corresponding author: Milica Mladenović

Metropolitan University Belgrade, Faculty of Management, Bulevar Svetog Cara Konstantina 80A, 18116 Niš, Serbia | E-mail: milica.mladenovic@metropolitan.ac.rs 
parts of life which both require as much time, energy and devotion (Hein, 2005). Since work and private life have become equally important for employees of both genders (Vandello et al., 2013), an interconnection or overlap of these two life spheres can be noticed, as presented in Figure 1, with events in each sphere affecting the other one (Lingard \& Francis, 2005).

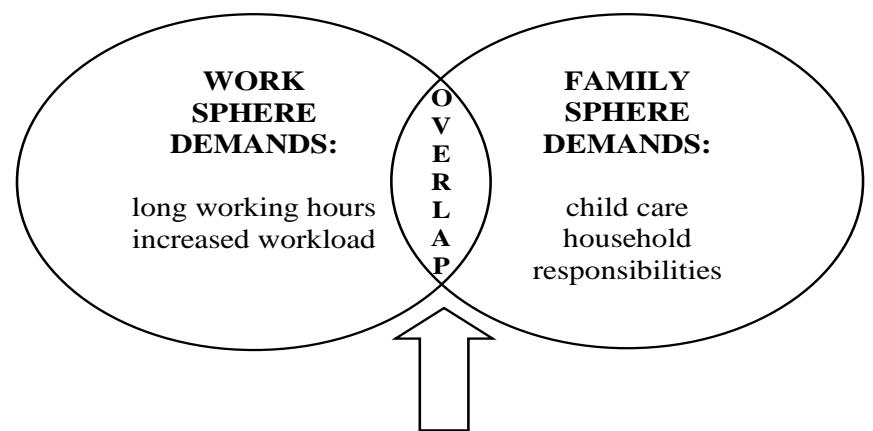

SOCIO-DEMOGRAPHIC CHANGES:

$$
\begin{gathered}
\text { increasing number of working women } \\
\text { families with both working parents } \\
\text { equal value of work/life balance for both genders } \\
\text { faster lifestyles }
\end{gathered}
$$

Fig. 1 Overlapping-spheres model of employees' work and private life Source: Adapted from: Liu, J. Y. \& Low, S. P. (2011). Work-Family Conflicts Experienced by Project Managers in Chinese Construction Industry. International Journal of Project Management, 29, 117-128.

Since both male and female employees are faced with limited resources, such as energy, time and attention, they are constantly assigning these limited resources to work and family activities, which together with long working hours and demanding jobs can cause imbalance between work and private life of employees (Korabik et al., 2008).

On the other hand, spending a sufficient amount of time on work as well as on private life responsibilities so that an individual is satisfied with both of these life spheres represents work-life balance (Mladenović, 2020). Experiencing lower levels of conflict and establishing work-life balance can significantly increase job satisfaction of employees (Naithani, 2010). Companies should manage work-life balance of their employees with a holistic approach, making it an integral part of their strategy and activities (Lukić \& Lazarević, 2018).

The aim of this paper is to emphasize the importance of both work and private life of employees, and also shed light on the interrelationship between these two life spheres. In the first part of the paper, a theoretical background on the terms of work-life conflict and work-life balance is given. Afterwards, results of various previously conducted research worldwide are presented in order to address the two research questions defined in the paper, concerning the type of interrelationship existing between work and private life of employees. Finally, the contribution of the paper can be seen in helping companies notice and understand the importance of establishing work-life balance of their employees, especially in the long run. 


\section{LITERATURE REVIEW}

\subsection{Different theoretical types and forms of conflict between work and private life of employees}

Conflict between work and private life can be viewed as "role overload" i.e. "simultaneous pressures" of employees' work and private life roles, where fulfilling each of the roles impedes fulfilling the other one (Greenhaus et al., 2000). Similarly, high role overload means having too many tasks and demands to fulfill in either role while having inadequate amount of time for that (Frone et al., 1992). Moreover, work-life conflict can be defined as an "inter-role conflict" or "push and pull" between pressures of employees' work responsibilities and private obligations (Burke \& Greenglass, 1999).

Hobson et al. (2001) considered work-life conflict to be a situation when employees fail to fulfill private life responsibilities because of work. Similarly, life-work conflict occurs when employees do not fulfill their work requirements due to private life obligations (Netemeyer et al., 2004). However, this should be happening repeatedly and in a longer time period for it to be considered a role conflict, i.e. singular cases cannot immediately be named work-life conflict.

There are two types of work-life conflict: namely, conflict from work interfering with private life, and conflict from private life interfering with work (Greenhaus et al., 2000). Furthermore, each type of conflict can have three forms as follows: conflict based on time, conflict based on strain, and conflict based on behavior (Nadeem, 2009). Table 1 shows that any characteristic of employees' work or private life that has an effect on their time, strain or behavior in either life sphere, may become a source of work-life conflict.

Table 1 Types and forms of conflict between work and private life

\begin{tabular}{|c|c|}
\hline Sources of WLC* based on time: & Sources of LWC $*$ based on time: \\
\hline $\begin{array}{l}\text { long working hours } \\
\text { inflexible work schedule } \\
\text { extensive overtime work } \\
\text { extensive shiftwork } \\
\text { extensive commute }\end{array}$ & $\begin{array}{l}\text { young children } \\
\text { large families } \\
\text { spouse's working hours }\end{array}$ \\
\hline Sources of WLC* based on strain: & Sources of LWC $*$ based on strain: \\
\hline $\begin{array}{l}\text { low leader support } \\
\text { stress in work communication }\end{array}$ & $\begin{array}{l}\text { low spouse support at home } \\
\text { spose's extremely different job position }\end{array}$ \\
\hline Sources of WLC* ${ }^{*}$ based on behavior: & Sources of LWC $*$ based on behavior: \\
\hline $\begin{array}{l}\text { demonstrating authority } \\
\text { not expressing emotions }\end{array}$ & $\begin{array}{l}\text { being warm and open } \\
\text { expressing emotions }\end{array}$ \\
\hline
\end{tabular}

Conflict from work interfering with private life (work-life conflict - hereinafter: WLC) represents an "inter-role conflict" where work pressures influence employees' private lives (Netemeyer et al., 1996). Similarly, Frone et al. (1992) view WLC as work responsibilities preventing employees from fulfilling their family obligations.

Spending an extensive amount of time on work reduces the time left for private obligations. This so-called WLC based on time can be created by different sources such as 
long working hours, inflexible work schedule, extensive overtime work, shiftwork or commute (Greenhaus et al., 2000).

Different types of work challenges, such as low leader support or stress in work communication, may cause tension or frustration, becoming sources of WLC based on strain (Jones \& Butler, 1980).

Certain behaviors developed at work, such as demonstrating authority and not expressing emotions, may not be suitable or desirable at home, therefore becoming sources of WLC based on behavior (Greenhaus et al., 2000). If people cannot switch their work behavior to adjust to the expectations of their role at home, they will often feel conflict between these two roles (Schein, 1973).

Conflict from private life interfering with work (life-work conflict - hereinafter: LWC), on the contrary, represents an "inter-role conflict" where pressures in employees' private lives affect fulfilling their work obligations (Netemeyer et al., 1996).

Spending time on private obligations, such as child care or household responsibilities, reduces the time available for work obligations (Voydanoff, 2007). This so-called LWC based on time can be developed by different sources, such as having a lot of children, especially young ones, or having a spouse with incompatible working hours (Greenhaus \& Kopelman, 1981).

Family demands, such as low spouse support in household responsibilities or spouse's extremely different job position, can lead to various strain symptoms such as stress or frustration, becoming sources of LWC based on strain (Greenhaus et al., 2000).

Certain behaviors adopted at home, such as being warm and emotional, may not be desirable or suitable at work, therefore becoming sources of LWC based on behavior (Voydanoff, 2007). Managers often feel "caught" between expected expression of emotions and openness at home, and expected demonstration of authority at work (Bartolome, 1972).

\subsection{Theoretical concept of balance between work and private life of employees}

As opposed to WLC, work-life balance (hereinafter: WLB) represents a positive condition of equilibrium, with employees feeling their work and private life as equally balanced (Lockwood, 2003). In other words, establishing WLB requires creating enough "weight" by focusing on work, while developing a positive "counterweight" by doing personal life activities (Mladenović, 2020).

Greenhaus \& Powell (2006) view WLB as mutual support of employees' work and private life in the sense that experiences in either life sphere of employees contribute to achieving success in the other one, thus making work and private life allies instead of enemies (Friedman \& Greenhaus, 2000).

Companies can implement some of the following human resources policies to decrease WLC and improve WLB of employees: flexible working hours, part-time work, support of the managers, stress management programs, counseling programs, parental leave, on-site or subsidized child care, health insurance or fitness programs (Lankeshwara \& Wijesekara, 2015).

An interesting view of WLB was presented by Frame and Hartog (2003), who considered it as the feeling of being able and free to use "flexible work initiatives" for balancing their work activities and private interests (e.g. family, hobby or travel), rather than focusing only on their job. However, this view puts emphasis solely on WLB initiatives, rather than considering 
additional factors, such as organizational culture, that can contribute to establishing WLB (Cerović \& Aleksić, 2005).

A different point of view could be considering WLB programs as a marketing or human resources tool for more successful recruitment and/or retention of employees (Frame $\&$ Hartog, 2003). These programs can indeed be a significant element of the company's differentiation on the labor market (Ivanović-Đukić \& Đorđević, 2005). That way, being perceived as innovative for offering WLB programs not only can enable a company to attract more quality employees, but it can also allow the company to develop and emphasize a reputation of a desirable employer (Lazăr et al., 2010). The most effective solution would certainly be offering these programs together with excellent basic job characteristics, such as salary, bonuses, and adequate job position. In the process of employer branding, companies should also strive to increase the level of satisfaction, commitment, motivation, and loyalty of their existing employees (Lukić et al., 2019).

\section{Methodology of ReSEARCH}

In order to discover the relationship (and possible interrelationship) between employees' work and private life, two questions for research and discussion are defined:

1. Are work and private life of employees negatively (inter)related i.e. is there WLC?

2. Are work and private life of employees positively (inter)related i.e. is there WLB?

These questions are addressed using document analysis method, which is a qualitative research method used to evaluate, identify, analyze, interpret and comprehensively synthesize the research results previously conducted by relevant authors, in order to provide background information, historical insight, and a deeper understanding of a particular research topic (Bowen, 2009).

Extensive literature reviewed and analyzed in this paper includes various scientific papers, journals, books, and publications containing empirical evidence from relevant and comprehensive previously conducted work-life studies and surveys on managers and other employees in various industries and countries, which were written in English or Serbian language, and available online by using the search terms "work-life relationship" as key words.

Document analysis identified two main theoretical concepts regarding the interrelationship between work and private life of employees. These are the concept of work-life conflict (Carlson et al., 2000; Liu \& Low, 2011; Hussain \& Mujtaba, 2012; Lankeshwara \& Wijesekara, 2015; Oosthuizen et al., 2016; Agha et al., 2017; Kim \& Kim, 2017; Pejičić \& Ranđelović, 2019; Lydeka \& Tauraite, 2020; Marič et al., 2021), and the concept of work-life balance (Grzywacz et al., 2002; Lambert \& Haley-Lock, 2004; Moore, 2007; Haar et al., 2014; Golubović \& Golubović, 2015; Adikaram \& Jayatilake, 2016; Fernandez-Crehuet et al., 2016; Stojanović-Aleksić \& Bošković, 2017; Marič \& Žnidaršič, 2018; Yusuf, 2018; Dilmaghani \& Tabvuma, 2019; Apraku et al., 2020). Both of these work-life concepts (conflict and balance) are further researched and analyzed in order to discover their types and forms.

Since more research has been conducted on the organizational than on the individual level of measuring WLC and WLB, with no universally recognized and accepted measurement methodology (Krasulja et al., 2015), the importance of further research and methodology development should be stressed. 


\section{RESULTS AND DISCUSSION}

\subsection{Negative (inter)relationship between work and private life of employees: research results}

Similarities can be noticed between the early and the contemporary papers published on the topic of work-life conflict, in the sense that striving to succeed in their careers and/or the desire to form a family have been influencing work and private lives of employees both in the past and at present, which can be noted in the following examples from previous research.

A study by Korman et al. (1981) found that managers who achieved high career success experienced greater WLC since it required extensive commitment to work demands, leaving less time available for private life.

Furthermore, Greenhaus \& Kopelman (1981) found that spouses of people who worked in management positions experienced greater $L W C$ based on strain than spouses of people in non-management positions.

Frone et al. (1992) determined a "bidirectional relationship" or interrelationship between work and private life, i.e. the possibility of both of these life spheres interfering with each other. Another conclusion of this research was that work obligations had a higher likelihood of affecting private life than vice versa.

Moreover, Parasuraman et al. (1996) discovered increased work overload to cause greater WLC. Having a large amount of demands from supervisors or other colleagues could lead to WLC, usually expressed as stress, dissatisfaction or even depression.

Research by Adams et al. (1996) showed that employees with young children and fulltime-employed spouses experienced greater $L W C$ based on time, compared to those whose spouses were unemployed or on paid leave.

Additional research was conducted by Frone et al. (1997), where 372 married employees with or without children answered questions regarding role overload, time commitment, role conflict and performance in both their work and private lives. This research showed that work overload (i.e. having too many work demands) was significantly negatively related to work performance (i.e. the level of fulfilling work responsibilities). On the other hand, parental overload (i.e. having too many children demands) did not significantly affect private life performance (i.e. the level of fulfilling private responsibilities).

In a survey by Wallace (1997), lawyers believed that work pressure led to their work interfering with their private lives in a negative way, creating WLC based on strain.

Carlson et al. (2000) measured WLC by including the three forms of conflict, as well as both directions of conflict, which is presented in Table 2. As in most cases, this type of research can be conducted by respondents completing questionnaires i.e. by rating certain statements on a 5-point Likert scale (Mladenović \& Krstić, 2021a).

Employees may often consider long working hours as an indicator of their commitment and productivity, which then makes them prioritize work over family, leading to a potential $W L C$ based on time, in the long run (Moore, 2007). Sometimes companies themselves can convey an indirect message to their employees that the duration of their working hours is an indicator of their work commitment (Korabik et al., 2008).

The results of a study on project managers in the construction industry in China conducted by Liu \& Low (2011) showed that the participants experienced significantly greater WLC than LWC based on time and strain, while at the same time experiencing the same WLC and LWC based on behavior. 
Table 2 Typical statements in the work-life conflict questionnaire

\begin{tabular}{|c|c|}
\hline Conflict type & Statement \\
\hline WLC based on time & $\begin{array}{l}\text { Spending a lot of time on completing work obligations oftentimes } \\
\text { leads to me missing activities with my family. }\end{array}$ \\
\hline WLC based on strain & $\begin{array}{l}\text { I oftentimes feel so emotionally drained or tired from work that I } \\
\text { cannot partake in activities with my family members. }\end{array}$ \\
\hline WLC based on behavior & Behavior that is useful at work would be counterproductive at home. \\
\hline LWC based on time & $\begin{array}{l}\text { Spending a lot of time on fulfilling private life demands oftentimes } \\
\text { prevents me from devoting enough time to work obligations. }\end{array}$ \\
\hline LWC based on strain & $\begin{array}{l}\text { I oftentimes think about private matters and family stress, which } \\
\text { makes it harder for me to focus on work. }\end{array}$ \\
\hline LWC based on behavior & Behavior that is useful at home may be ineffective at work. \\
\hline
\end{tabular}

Survey on employees of the National Database and Registration Authority (NADRA) in Pakistan showed high WLC, however with no significant difference regarding genders (Hussain \& Mujtaba, 2012). On the other hand, surprising results of this research showed a significantly positive effect of WLC on employee performance. These authors considered WLC, while remaining at a "functional level", as a positive driving force that could create the necessary motivation and increase employee performance. After reaching a certain "threshold level", WLC would eventually cause employee performance to decrease.

The research sample of Lankeshwara \& Wijesekara (2015) consisted of 120 non-executive employees of Ceylon Electricity Board (CEB) Office in Sri Lanka, who completed questionnaires on WLC. Their research concluded that both WLC and LWC negatively impacted job satisfaction, with a stronger influence of WLC.

A study by Oosthuizen et al. (2016) included 79 employees of an IT company in South Africa. Regarding ethnicity, white employees experienced significantly higher levels of job satisfaction than black employees. On the other hand, black employees felt significantly higher WLC than white employees.

A survey conducted by Agha et al. (2017) on 625 teachers from both private colleges and public universities in Oman showed that both WLC and LWC had a negative relationship with teachers' job satisfaction.

Research by Kim \& Kim (2017), including only female employees in Korea, discovered that married women with children experienced higher LWC than single women without children.

A study by Pejičić \& Ranđelović (2019) researched the influence of interpersonal relationships, both at work and at home, on WLC of 644 married employees with children in Serbia. Research results discovered a positive interrelationship between the quality of communication at home (with family members), and the quality of interpersonal relationships at work (with colleagues and superiors), which together led to lower WLC of employees.

A survey by Lydeka \& Tauraite (2020) assessed WLC of 406 male and female employees in Lithuania by comparing the allocation of time between their work and private lives. The main conclusion of this study was that both men and women prioritized work over their private lives. However, the results of this research also showed significant differences in time allocation between men and women, with men spending relatively more time on leisure and travel, compared to women who spent relatively more time on child care and housework. 
Additional conclusions of this study include a weak positive correlation between monthly salary and average time allocated to work, as well as a weak negative correlation between monthly salary and average time allocated to private life.

Recearch by Marič et al. (2021), focusing on the relationship between WLC and job satisfaction of high education lecturers from Serbia, Croatia, Slovenia, the Czech Republic, Austria, and Germany, did not show significant differences in WLC between these countries. However, the results showed that lower levels of WLC led to higher job satisfaction of high education lecturers.

\subsection{Positive (inter)relationship between work and private life of employees: research results}

In addition to work-life conflict, a positive effect of work and private lives of employees on each other has also been discovered in early papers and has been discussed up until now, which can be noticed in the following research examples.

Sieber (1974) claimed that success in either work or private life could sometimes compensate for stress or failure in the other life sphere. Moreover, positive experiences in one role, such as learning new communication skills, establishing new contacts or acquiring high levels of energy, can transfer and produce positive outcomes in the other role (Marks, 1977).

In a survey conducted on 163 full-time employees, Adams et al. (1996) found that conflict and support could simultaneously be present in work and private life of employees. Their results also showed that support of supervisors and/or spouses in the form of advice or practical help could reduce WLC of employees. Furthermore, establishing healthy WLB with the contribution of supportive managers could have a significant positive impact on job satisfaction of employees (Hussain \& Mujtaba, 2012). Frone et al. (1997) developed an "integrative model of work-life interface", which included factors of WLB as so-called "feedback loops" that connected work and private lives of employees in the form of social support by supervisors, colleagues or family members - this support can mean different things, from finding the time to talk and help the person feel better when upset, to sharing work tasks, household or child care responsibilities, thus reducing work or parental overload.

Tompson and Werner (1997) considered WLC and WLB as "opposite ends of the same continuum", with their research results showing substantially higher average WLB scores than the average WLC scores, suggesting that employees generally perceived the relationship between their work and private lives as mutual balance. Moreover, $23 \%$ of female managers reported that self-confidence and multitasking ability in their personal lives also positively impacted their managerial effectiveness (Ruderman et al., 2002).

Grzywacz et al. (2002) measured WLB in both directions, similarly to measuring WLC, where respondents completed questionnaires with statements rated on a 5-point Likert scale, which can be seen in Table 3. This research discovered a generally stronger positive influence of private life on work (life-work balance - hereinafter: $L W B$ ) than vice versa, i.e. WLB of employees.

Research on accessibility of WLB programs throughout the companies' organizational structure discovered that employees in the lower hierarchical levels of the companies were excluded i.e. they were either entirely or to a large extend not offered these programs (Lambert and Haley-Lock, 2004). 
Table 3 Typical statements in the work-life balance questionnaire

\begin{tabular}{ll}
\hline Balance type & Statement \\
\hline WLB $^{*}$ & $\begin{array}{l}\text { Achieving work success makes me cheerful and enthusiastic about handling my } \\
\text { private life obligations. } \\
\text { FWB }\end{array}$ \\
& Feeling loved and supported by family members increases my work confidence. \\
\hline $\begin{array}{r}\text { Source: } \\
\text { WhB - work-life balance, LWB - life-work balance }\end{array}$ \\
Work-Family Spillover and Daily Reports of Work and Family Stress in the Adult Labor Force. \\
Family Relations, 51, 28-36.
\end{tabular}

Two-year-long research on managers and other employees in an Anglo-German automobile company was conducted by Moore (2007) in the form of participant observation and in-depth interviews of employees in management and coordination functions, as well as shop floor workers, with Moore (2007) spending three months working as a "temporary employee" at the company's factory. The company was offering its managers different programs and tools such as the "wheel of life" in order to inspire them to recognize the significance of establishing WLB. This research showed that although most of company's WLB programs targeted managers, other employees were more successful in establishing WLB (by using shift work) since the UK managerial culture supported long working hours as a sign of productivity and commitment (Moore, 2007).

A study by Haar et al. (2014), investigating WLB of 1416 employees from China, Malaysia, New Zealand, France, Spain, and Italy, found that WLB was positively related to job satisfaction in all six countries.

Research by Golubović \& Golubović (2015) on employees in Serbia showed a significantly higher influence of work on their private lives than vice versa, with women experiencing more difficulties in establishing WLB than men.

A study conducted in 26 European countries by Fernandez-Crehuet et al. (2016) found a higher level of WLB in Northern and Central European countries, such as Denmark, Sweden, or Germany, compared to Southern and Western European countries, such as Italy, Greece, or Bulgaria.

A survey by Adikaram \& Jayatilake (2016) analyzed WLB factors, such as working hours, work pressure, and WLB programs. Research results discovered a positive influence of WLB on job satisfaction of employees in the private banking sector in Sri Lanka.

Companies in the service sector in Serbia have demonstrated very modest results in offering WLB programs, as well as in measuring job satisfaction of their managers and other employees (Stojanović-Aleksić \& Bošković, 2017).

A study conducted by Marič \& Žnidaršič (2018) researched how gender, age, and academic rank affected WLB among high education lecturers from Serbia, Croatia, Slovenia, the Czech Republic, Austria, and Germany. Research results showed a positive correlation between academic rank and WLB, but no significant difference in WLB as to gender or age.

In addition, a survey conducted on 200 employees in the business process outsourcing sector in India showed no significant difference in the level of established WLB between male and female employees (Yusuf, 2018).

Dilmaghani \& Tabvuma (2019) researched WLB of employees in ten major industries and they found that women working in the trading industry experienced higher WLB than men in this occupation, whereas women in management positions felt lower WLB than men in the same positions. 
Moreover, a survey conducted on 150 employees of small and medium companies in the construction industry showed a positive relationship between their WLB and company productivity (Apraku et al., 2020).

\section{CONCLUSION}

Families with both working parents, who are juggling between their job demands and household responsibilities, can often experience lower work performance and job satisfaction, which usually results in conflict between their work and private lives. Employees nowadays aspire to become able to successfully balance these two life spheres.

Numerous research results presented in this paper lead to confirming both research questions imposed in the paper. In other words, the document analysis of the presented research results has shown that both conflict and balance can exist as the type of relationship between employees' work and private life. Since research suggests that both work and private life roles of employees can affect each other positively or negatively, both WLB and WLC can be considered "bidirectional".

The contribution of this paper can be reflected in emphasizing that decreasing conflict and establishing balance between work and private life can significantly contribute to improving employee job satisfaction. Since companies have come to realize that offering WLB programs to their employees and managers could benefit the company by positioning it as a "top" employer on the market, human resource management of companies should focus on developing these programs in order to address this strategic issue in today's business world.

The limitations of this paper may be noticed due to the fact that the document research results included in the paper were from different industries and countries, making space for future empirical research in a specific country and industry in order to be able to reach a generalized conclusion in terms of research results.

\section{REFERENCES}

Adams, G. A., King, L. A., \& King, D. W. (1996). Relationships of Job and Family Involvement, Family Social Support and Work-Family Conflict with Job and Life Satisfaction. Journal of Applied Psychology, 81(4), 411-420. https://www.doi.org/10.1037/0021-9010.81.4.411

Adikaram, D. S. R., \& Jayatilake L. V. K. (2016). Impact of Work-Life Balance on Employee Job Satisfaction in Private Sector Commercial Banks of Sri Lanka. International Journal of Scientific Research and Innovative Technology, 3(11), 17-31.

Agha, K., Azmi, F. T., \& Irfan, A. (2017). Work-Life Balance and Job Satisfaction: An Empirical Study Focusing on Higher Education Teachers in Oman. International Journal of Social Science and Humanity, 7(3), 164-171. https://www.doi.org/10.18178/ijssh.2017.v7.813

Apraku, K., Bondinuba, F. K., Eyiah, A. K., \& Sadique, A. M. (2020). Construction Workers Work-Life Balance: A Tool for Improving Productivity in the Construction Industry. Social Work and Social Welfare, 2(1), 45-52. https://www.doi.org/10.25082/SWSW.2020.01.001

Bartolome, F. (1972). Executives as Human Beings. Harvard Business Review, 50 6), 62-69.

Bowen, G. A. (2009). Document Analysis as a Qualitative Research Method. Qualitative Research Journal, 9(2), 27-40. https://www.doi.org/10.3316/QRJ0902027

Burke, R. J., \& Greenglass, E. R. (1999). Work-Family Congruence and Work-Family Concerns among Nursing Staff. Canadian Journal of Nursing Leadership, 12(2), 21-29. https://www.doi.org/10.12927/cjnl.1999.19074

Carlson, D. S., Kacmar, K. M., \& Williams, L. J. (2000). Construction and Initial Validation of a Multidimensional Measure of Work-Family Conflict. Journal of Vocational Behavior, 56(2), 249-276. https://www.doi.org/10.1006/ jvbe.1999.1713 
Cerović, B., \& Aleksić, A. (2005). Culture for Business: The Serbian Perspective. In: Prašnikar, J. \& Cimerman, A. (Eds.), Globalno gospodarstvo in kulturna različitost (pp. 135-141). Ljubljana: Časnik Finance.

Dilmaghani, M., \& Tabvuma, V. (2019). The Gender Gap in Work-Life Balance Satisfaction across Occupations. Gender in Management: An International Journal. 34(5), 398-428. https://www.doi.org/10.1108/GM-092018-0109

Fernandez-Crehuet, J. M., Gimenez-Nadal, J. I., \& Reyes-Recio, L. E. (2016). The National Work-Life Balance Index: The European Case. Social Indicators Research: An International and Interdisciplinary Journal for Quality-of-Life Measurement, 128(1), 341-359. https://www.doi.org/10.1007/s11205-015-1034-2

Frame, P., \& Hartog, M. (2003), From Rhetoric to Reality. Into the Swamp of Ethical Practice: Implementing WorkLife Balance. Business Ethics: A European Review, 12(4), 358-367. https://www.doi.org/10.1111/14678608.00337

Friedman, S. D., \& Greenhaus, J. H. (2000). Allies or Enemies? What Happens when Business Professionals Confront Life Choices. New York: Oxford University Press.

Frone, M. R., Russell, M., \& Cooper, M. L. (1992). Antecedents and Outcomes of Work-Family Conflict: Testing a Model of the Work-Family Interface. Journal of Applied Psychology, 77(1), 65-78. https://www.doi.org/10.1037/ 0021-9010.77.1.65

Frone, M. R., Yardley, J. K., \& Markel, K. S. (1997). Developing and Testing an Integrative Model of the WorkFamily Interface. Journal of Vocational Behavior, 50(2), 145-167. https://www.doi.org/10.1006/jvbe.1996.1577

Golubović, N., \& Golubović, S. (2015). Comparative Analysis of Work-Life Balance in FYR Macedonia, Montenegro and Serbia. Facta Universitatis - Series: Economics and Organization, 12(3), 183-198.

Greenhaus, J. H., Callanan, G. A., \& Godshalk, V. M. (2000). Career Management. Fort Worth, TX: Harcourt College Publishers.

Greenhaus, J. H., \& Kopelman, R. E. (1981). Conflict between Work and Non-Work Roles: Implications for the Career Planning Process. Human Resource Planning, 4(1), 1-10.

Greenhaus, J. H., \& Powell, G. N. (2006). When Work and Family Are Allies: A Theory of Work-Family Enrichment. Academy of Management Review, 31(1), 72-92. https://www.doi.org/10.5465/amr.2006.19379625

Grzywacz, J. G., Almeida, D. M., \& McDonald, D. A. (2002). Work-Family Spillover and Daily Reports of Work and Family Stress in the Adult Labor Force. Family Relations: An Interdisciplinary Journal of Applied Family Studies, 51(1), 28-36. https://www.doi.org/10.1111/j.1741-3729.2002.00028.x

Haar, J. M., Russo, M., Suñe, A., \& Ollier-Malaterre, A. (2014). Outcomes of Work-Life Balance on Job Satisfaction, Life Satisfaction and Mental Health: A Study across Seven Cultures. Journal of Vocational Behavior, 85(3), 361-373. https://www.doi.org/10.1016/j.jvb.2014.08.010

Hein, C. (2005). Reconciling Work and Family Responsibilities: Practical Ideas from Global Experience. Geneva: International Labour Office.

Hobson, C. J., Delunas, L., \& Kesic, D. (2001). Compelling Evidence of the Need for Corporate Work-Life Balance Initiatives: Results from a National Survey of Stressful Life-Events. Journal of Employment Counselling, 38(1), 38-44. https://www.doi.org/10.1002/j.2161-1920.2001.tb00491.x

Hussain, R. I., \& Mujtaba, B. G. (2012). The Relationship between Work-Life Conflict and Employee Performance: A Study of National Database and Registration Authority Workers in Pakistan. Journal of Knowledge Management, Economics and Information Technology, 2(6), 1-5.

Ivanović-Đukić, M., \& Đorđević, A. (2005). Usklađivanje ljudskih resursa sa strategijom [Aligning Human Resources with Strategy]. Ekonomske teme, 17(2), 163-170.

Jones, A. P., \& Butler, M. C. (1980). A Role Transition Approach to the Stresses of Organizationally-Induced Family Role Disruption. Journal of Marriage and the Family, 42(2), 367-376. https://www.doi.org/10.2307/351234

Kim, H. K., \& Kim, Y. H. (2017). Work-Life Conflict of Married and Childless Single Female Workers. International Journal of Manpower, 38(8), 1157-1170. https://www.doi.org/10.1108/IJM-06-2015-0089

Korabik, K., Lero, D. S., \& Whitehead, D. L. (2008). Handbook of Work-Family Integration: Research, Theory and Best Practices. London: Academic Press.

Korman, A. K., Wittig-Berman, U., \& Lang, D. (1981). Career Success and Personal Failure: Alienation in Professionals and Managers. Academy of Management Journal, 24(2), 342-360. https://www.doi.org/10. $5465 / 255846$

Krasulja, N., Vasiljević-Blagojević, M., \& Radojević, I. (2015). Working from Home as Alternative for Achieving Work-Life Balance. Ekonomika, 61(2), 131-142. https://www.doi.org/10.5937/ekonomika1502131K

Lambert, S. J., \& Haley-Lock, A. (2004). The Organizational Stratification of Opportunities for Work-Life Balance. Community, Work and Family, 7(2), 179-195. https://www.doi.org/10.1080/1366880042000245461

Lankeshwara, P., \& Wijesekara, N. M. (2015). Impact of Work Life Conflict on Job Satisfaction: Special Reference to Ceylon Electricity Board - Sabaragamuwa Provincial Office. 2nd International Human Resource Management Conference, 2(1), 49-57. 
Lazăr, I., Osoian, C., \& Raţiu, P. (2010). The Role of Work-Life Balance Practices in Order to Improve Organizational Performance. European Research Studies, 13(1), 201-213.

Lingard, H., \& Francis, V. (2005). The Decline of the Traditional Family: Work-Life Benefits as a Means of Promoting a Diverse Workforce in the Construction Industry of Australia. Construction Management and Economics, 23(10), 1045-1057. https://www.doi.org/10.1080/01446190500394308

Liu, J. Y., \& Low, S. P. (2011). Work-Family Conflicts Experienced by Project Managers in Chinese Construction Industry. International Journal of Project Management, 29(2), 117-128. https://www.doi.org/10.1016/j.ijproman. 2010.01.012

Lockwood, N. R. (2003). Work-Life Balance: Challenges and Solutions. Alexandria, VA: Society for Human Resource Management.

Lukić, J., Brkljač, M., \& Perčić, K. (2019). Brendiranje poslodavaca u funkciji privlačenja i zadržavanja talenata koji pripadaju generaciji milenijalaca [Employer Branding for Recruitment and Retention of Talented Employees belonging to the new Generation of Millennials]. Marketing, 50(2), 83-93. https://www.doi.org/10.5937/markt1902083L

Lukić, J., \& Lazarević, S. (2018). Sources of Workplace Stress in Service Sector Organizations. Facta Universitatis, Series: Economics and Organization, 15(3), 217-229. https://www.doi.org/10.22190/FUEO1803217L

Lydeka, Z., \& Tauraite, V. (2020). Evaluation of the Time Allocation for Work and Personal Life among Employed Population in Lithuania from Gender Perspective. Inžinerine Ekonomika - Engineering Economics, 31(1), 104-113. https://www.doi.org/10.5755/j01.ee.31.1.23056

Marič, M., Todorović, I., \& Žnidaršić, J. (2021). Relations between Work-Life Conflict, Job Satisfaction and Life Satisfaction among Higher Education Lecturers. Management: Journal of Sustainable Business and Management Solutions in Emerging Economies, 26(1), 63-72. https://www.doi.org/10.7595/management.fon.2021.0008

Marič, M., \& Žnidaršič, J. (2018). The Effect of Gender, Age and Academic Rank on Work-Life Balance, Škola biznisa, 2, 1-11. https://www.doi.org/10.5937/skolbiz2-20983

Marks, S. R. (1977). Multiple Roles and Role Strain: Some Notes on Human Energy, Time and Commitment. American Sociological Review, 42(6), 921-936. https://www.doi.org/10.2307/2094577

Mladenović, M. (2020). Ravnoteža između poslovnog i privatnog života zaposlenih i menadžera - pogodnosti za balansiranje života i njihovi efekti [Equilibrium between Business and Private Life of Employees and Managers - Benefits for Balance of Life and Their Effects]. Ekonomski izazovi, 9(17), 67-79. https://www.doi.org/10.5937/EkoIzazov2017067M

Mladenović, M., \& Krstić, B. (2021a). Barriers and Measurement of Work-Life Balance of Managers and Other Employees. Economics of Sustainable Development, 5(1), 23-31. https://www.doi.org/10.5937/ESD2101023M

Mladenović, M., \& Krstić, B. (2021b). Trends and Strategic Approach to Establishing Work-Life Balance of Managers and Other Employees. Economics of Sustainable Development, 5(2), 29-36. https://www.doi.org/10.5937/ ESD2102029M

Moore, F. (2007). Work-Life Balance: Contrasting Managers and Workers in an MNC. Employee Relations, 29(4), 385-399. https://www.doi.org/10.1108/01425450710759217

Nadeem, M. S. (2009). The Impact of Work Life Conflict on Job Satisfactions of Employees in Pakistan. International Journal of Business and Management, 4(5), 63-83. https://www.doi.org/10.5539/ijbm.v4n5p63

Naithani, P. (2010). Overview of Work-Life Balance Discourse and Its Relevance in Current Economic Scenario. Asian Social Science, 6(6), 148-155. https://www.doi.org/10.5539/ass.v6n6p148

Netemeyer, R. G., Boles, J. S., \& McMurrian, R. (1996). Development and Validation of Work-Family Conflict and Family-Work Conflict Scales. Journal of Applied Psychology, 81(4), 400-410. https://www.doi.org/10.1037/00219010.81.4.400

Netemeyer, R. G., Brashear-Alejandro, T., \& Boles, J. S. (2004). A Cross-National Model of Job Related Outcomes of Work Role and Family Role Variables: A Retail Sales Context. Academy of Marketing Science, 32(1), 49-60. https://www.doi.org/10.1177\%2F0092070303259128

Oosthuizen, R. M., Coetzee, M., \& Munro Z. (2016). Work-Life Balance, Job Satisfaction and Turnover Intention amongst Information Technology Employees. Southern African Business Review, 20(1), 446-467. https://www.doi.org/10.25159/1998-8125/6059

Parasuraman, S., Purohit, Y. S., Godshalk, V. M., \& Beutell, N. J. (1996). Work and Family Variables, Entrepreneurial Career Success and Psychological Well-Being. Journal of Vocational Behavior, 48(3), 275300. https://www.doi.org/10.1006/jvbe.1996.0025

Pejičić, M., \& Ranđelović, K. (2019). Značaj porodičnog funkcionisanja i međuljudskih odnosa na poslu za doživljaj konflikta između posla i porodice [The Role of Family Functioning and Interpersonal Relations at Work in WorkFamily Conflict]. Godišnjak za psihologiju, 16, 157-173. https://www.doi.org/10.46630/gpsi.18.2019.10

Ruderman, M. N., Ohlott, P. J., Panzer, K., \& King, S. N. (2002). Benefits of Multiple Roles for Managerial Women. Academy of Management Journal, 45(2), 369-386. https://www.doi.org/10.5465/3069352 
Schein, V. E. (1973). The Relationship Between Sex Role Stereotypes and Requisite Management Characteristics. Journal of Applied Psychology, 57(2), 95-100. https://www.doi.org/10.1037/h0037128

Sieber, S. D. (1974). Toward a Theory of Role Accumulation. American Sociological Review, 39(4), 567-578. https://www.doi.org/10.2307/2094422

Stojanović-Aleksić, V., \& Bošković, A. (2017). Društvena odgovornost preduzeća i etičko liderstvo [Social Responsibility of Enterprises and Ethical Leadership]. Economics of Sustainable Development, 1(2), 71-84.

Tompson, H. B., \& Werner, J. M. (1997). The Impact of Role Conflict/Facilitation on Core and Discretionary Behaviors: Testing a Mediated Model. Journal of Management, 23(4), 583-601. https://www.doi.org/10.1177/ 014920639702300405

Vandello, J. A., Hettinger, V. E., Bosson, J. K., \& Siddiqi, J. (2013). When Equal Isn't Really Equal: The Masculine Dilemma of Seeking Work Flexibility. Journal of Social Issues, 69(2), 303-321. https://www.doi.org/10.1111/ josi. 12016

Voydanoff, P. (2007). Work, Family and Community: Exploring Interconnections. Mahwah: Lawrence Erlbaum.

Wallace, J. E. (1997). It's about Time: A Study of Hours Worked and Work Spillover among Law Firm Lawyers. Journal of Vocational Behavior, 50(2), 227-248. https://www.doi.org/10.1006/jvbe.1996.1573

Yusuf, S. (2018). A Comparative Study of Work-Life Balance and Job Satisfaction of the Employees Working in Business Process Outsourcing Sector. IRA - International Journal of Management \& Social Sciences, 10(2), 87-93. https://www.doi.org/10.21013/jmss.v10.n2.p3

\section{ODNOS IZMEĐU POSLA I PRIVATNOG ŽIVOTA ZAPOSLENIH - KONFLIKT ILI USKLAĐENOST?}

U savremenim preduzećima, usklađenost posla $i$ privatnog života smatra se krucijalnom temom. Veći radni pritisak, duže radno vreme $i$ veći broj porodica sa oba zaposlena roditelja dodatno su otežali usklađivanje posla i privatnog života. U radu se definišu dva istraživačka pitanja vezana za pozitivni ili negativni tip odnosa između posla i privatnog života zaposlenih. Na ova pitanja su dati odgovori na osnovu analize različitih prethodno sprovedenih empirijskih istraživanja. Rezultati istraživanja otkrivaju kako negativan tako i pozitivan međusobni odnos između posla i privatnog života zaposlenih. Zaključci ovog rada mogu biti izuzetno relevantni za preduzeće kako bi se shvatila važnost primene praksi za usklađivanje posla i privatnog života za povećanje zadovoljstva poslom svojih menadžera i ostalih zaposlenih, kao i za razvijanje reputacije poželjnog poslodavca.

Ključne reči: konflikt između posla i privatnog života, usklađenost posla i privatnog života, zadovoljstvo poslom 